\title{
PROMET URBANEGA OBMOČJA LJUBLJANE IN MÜNSTRA
}

\author{
Špela Verovšek \\ Godič 17/c, SI-1242 Stahovica \\ e-mail: spela_verovsek@yahoo.com
}

\section{Strokovni članek}

COBISS 1.04

\section{Izvleček}

Prispevek obravnava in primerja strukturo, razvoj in ureditev prometa v Ljubljani in Münstru. Prikazani so temeljni elementi in kazalci integralnega prometnega sistema izbranih dveh mest in njunega gravitacijskega zaledja, ki se nanašajo na prostorsko organizacijo dejavnosti, prometne tokove, strukturo prometnih sistemov in način urejanja prometa. V prispevku je opredeljena tudi analiza potovalnih navad prebivalcev ter intenziteta cestno prometnih tokov na prehodu iz širše regije v mesto.

Ključne besede: prometno načrtovanje, javni promet, trajnostna mobilnost, potovalne navade, Ljubljana, Münster, Ljubljanska urbana regija, Münsterland

\section{TRAFFIC OF LJUBLJANA AND MÜNSTER URBAN AREAS}

\begin{abstract}
The article presents an attempt to compare traffic indicators and the state of traffic in Ljubljana and Münster and their gravitational hinterland. The purpose is to present individual aspects of passenger traffic system of Ljubljana and Münster and to deal with their traffic connectedness with a wider urban space. The work defines also the analysis of inhabitants' travelling habits and the intensity of road traffic flows at the passage from a broader area to a city.
\end{abstract}

Key words: traffic planning, public traffic, sustainable mobility, travelling habits, Ljubljana, Münster, Ljubljana urban region, Münsterland 


\section{UVOD}

Dinamičen pretok blaga, ljudi, storitev in informacij je ena izmed temeljnih značilnosti razvitih družb, saj omogoča njihov gospodarski in družbeni razvoj. Dosežena stopnja razvoja v današnjem času, hkrati pa tudi vse višja stopnja udeleženosti prebivalstva v motoriziranem prometu, povečujejo potrebo po hitri, učinkoviti mobilnosti.

Ljubljana na področju urejanja prometa in trajnostne mobilnosti zaostaja v razvoju, kar povzroča številne probleme, kot so prekomerna raba osebnih avtomobilov, presežena zmogljivost cest, pomanjkanje parkirnih mest, slaba dostopnost, dolgi potovalni časi, prekomerna onesnaženost zraka in podobno. Ti problemi stihijskega razvoja prometa se kažejo v vseh komponentah prostora, tako družbeni, gospodarski kot okoljski. Hkrati pa neuravnoteženost na vseh omenjenih področjih prostora, znova vpliva na spremenjene razmere v prometu. Münster, kot protiutež Ljubljani, sicer v številnih geografskih kazalcih izkazuje podobnost s slovensko metropolo, vendar se z vidika razvoja in strukture prometa mesti pomembno razlikujeta.

$\mathrm{Z}$ namenom proučitve razvoja, stanja in teženj potniškega prometa v Mestni občini Ljubljana in okrožju Stadt Münster, smo sprva opravili klasično analizo posamičnih geografskih elementov, ki smo jih nato vključili v primerjalno analizo.

Primerjalna analiza, kot temeljna metoda raziskovanja, je bila namenjena vrednotenju posameznih kazalcev, tako v okviru primerjave dveh mest, kot primerjavi določenega kazalca v določenem časovnem obdobju. V začetnem delu raziskovanja smo najprej analizirali in primerjali osnovne družbeno-geografske kazalce (demografski razvoj, struktura gospodinjstev, stanovanjska problematika, zaposlitvene zmogljivosti, migracijski tokovi, urbanistična zasnova mesta, poselitveni vzorec v širši mestni regiji, gospodarska usmerjenost, izstopajoče funkcije mesta itd.), ki posredno vplivajo na prometne tokove in so podlaga za razumevanje le-teh. Zatem smo analizirali in primerjali posamezne prometne kazalce po različnih prometnih podsistemih, analizirali smo povprečne dnevne obremenitve nekaterih cest ter opravili primerjavo po kazalcih potovalnih navad prebivalstva. Domala vse kazalce smo predstavili v časovnem prerezu zadnjih 15 -ih let. Nekaj glavnih ugotovitev predstavljamo v sledečem prispevku.

\section{OPREDELITEV PROBLEMA}

Mesta in njihove regije $z$ veliko gostoto prebivalstva so vedno bolj tipičen vzorec poselitve $\mathrm{v}$ Evropi in hkrati področja $\mathrm{z}$ intenzivnim prometom in kompleksnim prometnim sistemom.

V dobro organiziranem mestu večja koncentracija zagotavlja vitalnost in razvoj, vendar ima lahko tudi negativne učinke: prometne zastoje in kaos, onesnaževanje, hrupnost, odtujenost prebivalstva, izgubo sredine, negotovost itd. Zato se vse več ljudi odloča za bivanje v neposredni okolici večjih mest. Posledica je širitev mesta navzven, kar povzroča negativne učinke predvsem $\mathrm{v}$ prometnih obremenitvah, pa tudi v izgubi odprtega naravnega prostora, neracionalni gradnji itd (Šašek-Divjak, 2004, str.76). 
Osnovno vprašanje pri obravnavi prometa je, kako doseči nemoten pretok ljudi in blaga zaradi zagotavljanja kakovosti družbeno-ekonomskega razvoja, ter na drugi strani varovanje okolja in zagotavljanje kakovosti bivanja prihodnjim rodovom (Trajnostna mobilnost, 2007).

Ljubljana in Münster kažeta visoko stopnjo centralnosti in dominantno vlogo v širšem urbanem prostoru, hkrati pa močno funkcijsko navezanost na suburbanizirano pokrajino $\mathrm{V}$ okolici. S tem je tudi njun prometni sistem kompleksnejši, potovalni tokovi intenzivnejši, mesti pa zahtevata za učinkovito funkcioniranje premišljeno rabo prostora in trajnostno prometno politiko. V tem smislu Münster s svojimi ukrepi urejanja prostora in prometa, že vrsto let uresničuje načela trajnostnega razvoja, kar se kaže v kakovosti bivanja in dobri funkcionalnosti prostora. Ljubljana zaenkrat izkazuje šele začetne faze urejanja prometa in načrtovanja prostora nasploh.

\section{PRIMERJAVA OSNOVNIH ZNAČILNOSTI LJUBLJANE IN MÜNSTRA}

Ljubljana ima centralno vlogo v širšem gravitacijskem območju, ki predstavlja demografsko, gospodarsko in prometno zelo dinamičen prostor. V letih po osamosvojitvi se število prebivalstva zmanjšuje na račun razseljevanja v suburbanizirano okolico, vendar se njen pomen zaradi tega ne zmanjšuje. Zgoščenost poselitve in visoka gostota prometne infrastrukture v gravitacijskem zaledju mesta se v zadnjem desetletju še stopnjuje. Poselitev se zgoščuje predvsem ob prometnih koridorjih, v večji oddaljenosti od mesta pa tudi stihijsko in razpršeno, kar je neugodno za organizacijo javnega prometa. Močno je izražena bivalna funkcija bližnjih naselij in pomanjkanje delovnih mest ter storitvenih in oskrbnih dejavnosti.

Münster ima centralno lego v regiji Münsterland, v severnem delu Zvezne dežele Nordrhein-Westfalen v Nemčiji. Skladno s težnjami v drugih monocentričnih zgostitvenih regijah tudi v Münsterlandu raste število prebivalstva po letu 1990, predvsem v okoliških prostorskih enotah, v samem Münstru pa je rast opazno nižja oziroma se v zadnjih letih rahlo izboljšuje predvsem zaradi raznovrstnih ukrepov, s katerimi želijo pritegniti okoliške prebivalce oziroma zaustaviti izseljevanje v okoliške občine. Za razliko od Ljubljane, se zgostitve prebivalstva v širši regiji niso oblikovale stihijsko ob glavnih komunikacijskih koridorjih, pač pa načrtno (model decentralizirane koncentracije) in hierarhično v obliki manjših centrov v regiji. To je tudi posledica še vedno močnega hierarhičnega centralnega sistema naselij, ki je na račun ravnega reliefa dokaj simetričen. $Z$ ohranjanjem policentričnega sistema zgoščevanja, se zmanjšuje negativni vpliv razpršene in stihijske gradnje, kar omogoča bolj rentabilen komunikacijski sistem.

Gibanje števila prebivalstva obeh mest je v daljšem razdobju podobno. Obe mesti kažeta rast števila prebivalstva do konca osemdesetih let, nato pa je število začelo padati. Upad in stagnacija prebivalstva sovpadata $\mathrm{z}$ dogodki in pretresi, ki so se dogajali konec 80 -ih in začetek 90-ih let (padec Berlinskega zidu, razpad Jugoslavije) in so povzročili tudi mnoge migracijske tokove. 
Preglednica 1: Primerjava osnovnih geografskih značilnosti Ljubljane in Münstra Table 1: The comparison of basic geographic indicators of Ljubljana and Munster

\begin{tabular}{|l|c|c|}
\hline & LJUBLJANA & MÜNSTER \\
\hline Ime enote & Mestna občina Ljubljana & Kreisfreie Stadt Münster \\
\hline Površina $\left(\mathrm{v} \mathrm{km}^{2}\right)$ & $275 \mathrm{~km}^{2}$ & $302,89 \mathrm{~km}^{2}$ \\
\hline Število prebivalcev (2006) & 267.387 & 271.369 \\
\hline Relief & ravninski (kotlinska lega) & ravninski \\
\hline Gostota prebivalstva (preb./ $\left.\mathrm{km}^{2}\right)$ & 972 & 898 \\
\hline Delež preb. starejšega od 65 let & $17 \%$ & $16,4 \%$ \\
\hline Št. gospodinjstev (2005) & 105.725 & 139.682 \\
\hline Št. ljudi/gospodinjstvo & 2,6 & 1,9 \\
\hline & Ljubljanska urbana regija & Münsterland \\
\hline Površina (v km $\left.{ }^{2}\right)$ & 2.555 & 5.940 \\
\hline Število prebivalcev (2006) & 502.100 & 1.500 .900 \\
\hline Gostota prebivalstva (preb./ $\left./ \mathrm{km}^{2}\right)$ & 196 & 252 \\
\hline
\end{tabular}

Vir: Jahres Statistik-Stadt Münster, 2006; Služba za mestno statistiko in analize MOL, 2006; SURS, 2006.

Število prebivalstva v Münstru je od srede 90-ih let naprej stabilno in v zadnjih letih celo narašča. Število gospodinjstev narašča mnogo hitreje kot število prebivalstva, kar pomeni, da se gospodinjstva stalno drobijo in so v povprečju celo manjša od dveh članov. V Ljubljani zadnja leta število prebivalstva še vedno upada. Število gospodinjstev ostaja na nižji ravni (jih je manj in so večja) kot v Münstru, kar je bolj ugodno in v načelu manj potratno, tako z vidika skupne rabe avtomobilov, kot tudi drugih oblik porabe energije.

\section{DNEVNI MIGRACIJSKI TOKOVI}

Tako Ljubljana kot Münster imata gravitacijsko zaledje, ki je tesno povezano z mestom. Poleg svojega lastnega prometa se soočata tudi z dnevnimi prometnimi pritiski zaradi dnevnih migrantov in tranzita.

Preglednica 2: Primerjava zaposlitvenih kazalcev Ljubljane in Münstra za leto 2002

Table 2: A comparative analysis of employement indicators in Ljubljana and Münster, 2002

\begin{tabular}{|l|c|c|}
\hline & LJUBLJANA & MÜNSTER \\
\hline Število vseh zaposlitvenih mest * & 182.284 & 184.400 \\
\hline Delovno aktivni kontigent prebivalstva & 130.122 & 130.483 \\
\hline Občani mesta zaposleni v občini bivanja & 102.231 & 90.004 \\
\hline Občani mesta zaposleni izven občine bivanja & 13.648 & 29.883 \\
\hline Dnevni delovni migranti iz okoliških občin & 67.443 & 79.405 \\
\hline
\end{tabular}

Vir: Jahres Statistik - Stadt Münster, 2006; SI-STAT:Popis 2002, (citirano 22.2.2007) * leto 2005 
Eden glavnih dejavnikov, ki vplivajo na obseg prometnih tokov, je v obeh mestih njuna močna zaposlitvena vloga. V Ljubljani in Münstru stalno raste število delovnih mest. $\mathrm{Ob}$ podobnih predispozicijah delovno aktivnega kontingenta prebivalstva v obeh mestih, je delež nezasedenih delovnih mest velik in predstavlja priložnost za zaposlovanje okoličanov. Delež dnevnih delovnih migrantov vseh zaposlenih v Ljubljani je 40\%, v Münstru pa celo 47\%. Pri tem je v Münstru tudi obratni tok zaposlovanja večji (iz mesta v okolico), kar sprošča še več zaposlitvenih mest za okoličane ter hkrati vpliva na povečane tokove ob konicah tudi v obratni smeri. Skratka, dnevni delovni tokovi se povečujejo predvsem na račun migrantov iz okolice, vendar v primeru Münstra tudi delež obratnega toka (okoli 30.000 ljudi) ni zanemarljiv.

Velik del dnevnih tokov predstavlja tudi dnevna migracija zaradi šolanja, saj tako Ljubljana, kot Münster predstavljata močan izobraževalni center in sedež univerze. V Ljubljani se letno izobražuje povprečno 70.000 študentov in dijakov, od katerih je $60 \%$ dnevnih vozačev. V Münstru je, pri podobnem številu šolajočih (77.000), okoli 40\% dnevnih migrantov.

Poleg delovnih dnevnih migrantov in študentov ter dijakov, predstavljajo pomemben delež v prometnih tokovih tudi prostočasne dejavnosti in oskrbovanje. V Ljubljani prevladuje slednje, saj ima mesto več večjih nakupovalnih središč, v Münstru pa ta funkcija ni tako izpostavljena. Münster je veliko bolj znan po številnih možnostih za preživljanje prostega časa (rekreacija, kultura, umetnost, prireditve), kar privablja številne obiskovalce.

Ocene kažejo, da obišče Münster dnevno iz različnih namenov okoli 115.000 ljudi, v Ljubljani pa naj bi bilo na običajni delovni dan približno 110.000 obiskovalcev (Verkehr in Zahlen, 2007; Upravljanje in brzdanje mestneg prometa, 2006).

\section{URBANISTIČNA ZASNOVA}

Ljubljana ima značilno radialno-krakasto prostorsko zasnovo. Zvezdasta struktura se širi v sedmih krakih navzven proti obrobju in narekuje smer razvoja v širšo urbanizirano okolico. Tudi Münster se, v sicer manj pravilni obliki, razširja iz jedra proti obrobju v štirih krakih, ki pa se praviloma (razen enega kraka) ne raztezajo vzdolž vpadnih cest, tako kot pri Ljubljani.

V Ljubljani se ti razvojni kraki raztezajo ob smereh vpadnih cest in predstavljajo območja zgoščevanja prebivalstva, največ delovnih mest, najvišje gostote prebivalstva ter visoko gostoto oskrbnih centrov, ki do določene mere slabijo sámo jedro in hierarhijo mesta. Krakasta zasnova je izrazito primerna za linijski promet, neprimerna pa za osebni avto. Zato se največje težave in največja nemoč tega prometnega sredstva kaže prav v mestnem središču, kjer se v največji meri pokaže neskladje med podedovano urbanistično zasnovo mesta in množično rabo osebnega avtomobila (Guzelj, 2001).

Za razliko od Ljubljane ima Münster močno in kompaktno jedro s posameznimi prostorsko ločenimi subcentri v okolici. Le-ti razbremenjujejo in uravnotežajo sestavo mesta. Tudi omenjeni kraki strnjene zazidave so krajši in striktno ločeni od subcentrov, saj že od 80-ih let z različnimi ukrepi skušajo zajeziti razlivanje zazidave ob vpadnicah ter krepiti center. Tovrstno usmerjanje zazidave, torej, zgoščevanje samega jedra mesta ter hkrati lociranje 
manjših otokov strnjene zazidave na obrobju, je potrjeno uspešen model razvoja mešane rabe tal in ohranjanja jasnih prostorskih mej med posameznimi rabami zemljišč. Omenjeni obliki mestnega tkiva sledjo hierarhično razporejeni oskrbni centri, tem pa sledi razporeditev stanovanj, šol in drugih storitev. V mestu se načrtuje še več mešane rabe zemljišč za bolj učinkovito uresničevanje koncepta t.i. »mesta kratkih poti«, ki znižuje razdalje med dejavnostmi in potrebo po mobilnosti.

\section{STRUKTURA CESTNEGA OMREŽJA}

Strukturo cest v Ljubljani v prvi vrsti zaznamujejo zvezdasto razporejene vpadnice, od katerih se štirje glavni kraki zaključujejo v mestnem središču. Povezovalni in distributivni cestni obroč okoli notranjega mestnega jedra ni v celoti zaključen, še manj izrazit pa je drugi mestni obroč, ki na več odsekih ni povezan. Zunanji avtocestni obroč je v celoti izgrajen in ga tvorijo tranzitne avtoceste in severna obvozna cesta.

Tudi v Münstru je cestno prometna struktura oblikovana po načelu napajalnih cest in koncentričnih obročev, torej radialno-koncentrično. Za razliko od Ljubljane je prvi, notranji obroč zelo izrazit in v celoti povezan, prav tako dosledno izgrajen je tudi drugi povezovalni obroč, ki v večini poteka okoli kompaktnega dela mesta. Zunanji, tretji obroč poteka samo po južni strani (južna obvozna štiripasovnica), na zahodni strani pa temu služi trasa avtocestne povezava A1, ki obide mesto. V Münstru se nobena od vpadnih cest ne stika v mestnem središču, pač pa se vse zaključujejo na notranjem cestnem obroču, saj je v jedru motorni promet zelo omejen.

\section{UREJANJE PROMETA $\vee$ MESTNEMJEDRU}

V Münstru se znotraj notranjega cestnega obroča motorni promet omejuje, organiziran pa je v večji meri krožno, s številnimi enosmernimi ulicami. Staro jedro je v načelu prevozno le za nekaj linij avtobusnega potniškega prometa.

V Ljubljani je znotraj notranjega obroča promet v veliki meri odprt za vse vrste prometa. Največji problem predstavlja stik vpadnic v samem centru, ki je zaradi tega močno obremenjen s ciljnim in tranzitnim prometom, vse pa vpliva na onesnaženost zraka, prekomeren hrup, pomanjkanje parkirnih mest itd. Široke prometnice visokih zmogljivosti v središču neugodno vplivajo tudi na vizualno raven mesta, hkrati pa močno ločujejo prostor.

Za ureditev motornega prometa v Ljubljani - predvsem v ožjem središču - obstajajo številne študije in projekti, vendar se v zadnjih 20 letih, razen manjših projektov, večina predlogov ni uresničila. V Münstru so za razliko od Ljubljane, v zadnjih petnajstih letih večkrat preuredili prometni režim središča, $v$ iskanju najboljše rešitve in optimizacije stanja.

\section{MOTORNI IN MIRUJOČI PROMET}

V Ljubljani se kaže prenasičenost mestnega jedra z motornim prometom preko rednih zastojev in zmanjšane pretočnosti cest, kar še posebej vpliva na onesnaževanje zraka 
(Prostorska zasnova MOL, 2002). Kljub nekaterim delnim ukrepom, kot je zapora za individualni motorizirani promet od Kongresnega trga do tržnice, so zmogljivosti notranjih cest presežene, delež potovanj z avtomobilom pa iz leta v leto raste in znaša že skoraj $68 \%$ od vseh opravljenih poti. Zelo obremenjeni so v Ljubljani tudi odseki avtocestnega obroča, posebej na severnem delu, kjer danes vrednosti povprečnega letnega dnevnega prometa (PLDP) znašajo med 60.000 do 70.000 avtomobilov dnevno. Stopnja rasti na teh odsekih od leta 1992-2004 znaša v povprečju 120\% (Podatki o štetju prometa na državnih cestah RS, 1992-2005).

Slika 1: Vrednosti PLDP na odsekih severnega dela ljubljanske obvoznice; 1999-2005

Figure 1: Average daily traffic intensity (cars/24h) on the sections of Ljubljana highway ring

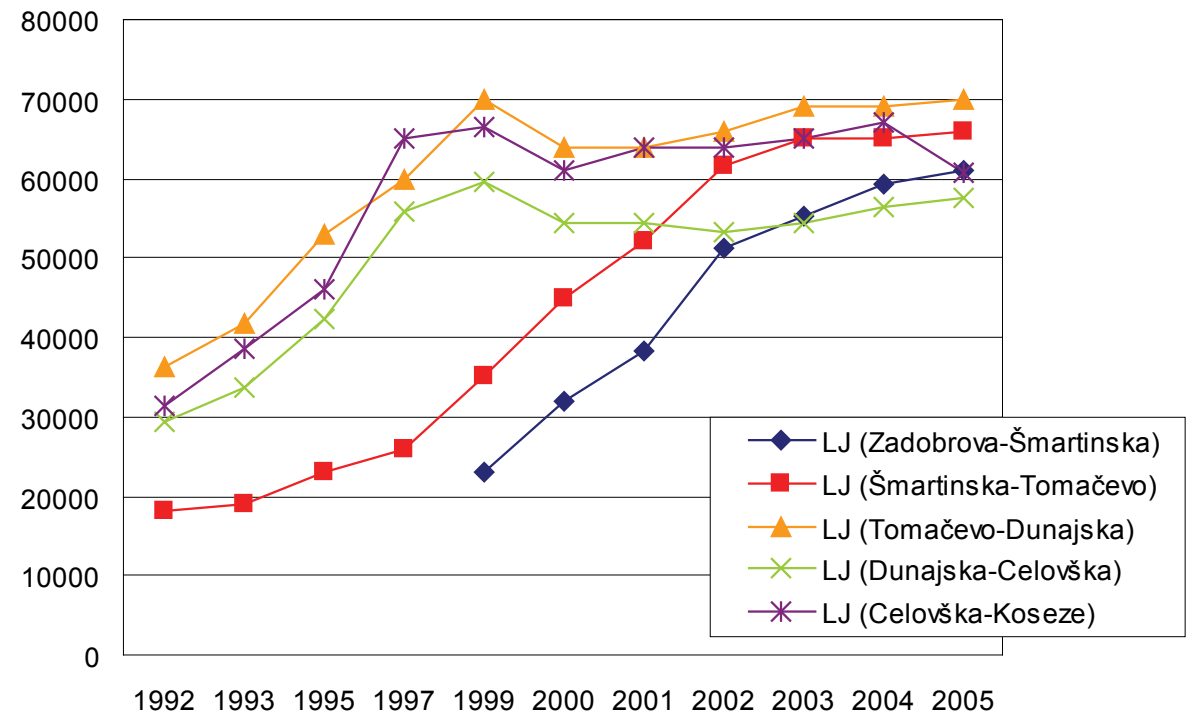

Vir: Podatki o štetju prometa na državnih cestah RS; 1992-2005

V Münstru motorni promet ne povzroča večjih težav, saj je avtomobilskega prometa le 40\% (Verkehrsbild, 2003), avtomobilske tokove pa se skuša združevati v zbirne in distributivne ceste izven jedra. Intenziteta prometa tudi na najbolj obremenjenih predelih zunanjega obroča ne presega 60.000 avtomobilov dnevno, v povprečju pa se vrednosti gibljejo med 30.000 in 50.000 avtomobili. Stopnja rasti intenzitete prometa od 1993 do 2004 na zunanjem obroču je v povprečju 52\%, v nadaljevanju smeri proti centru pa le dobre $4 \%$.

Glede na prevlado individualnega motornega prometa v Ljubljani, stalno primanjkuje tudi prostih parkirnih mest, posebej v ožjem mestnem območju, čeprav naj bi bilo na razpolago 12.000 parkirnih mest na parkiriščih, v parkirnih hišah in obcestnih pasovih parkiranja (Parkirišča Ljubljana, 2007). V Ljubljani že več let stalno potekajo razprave (trenutno o smotrnosti parkirne hiše pod ljubljansko tržnico) glede novih parkirišč, cene parkiranja, 
smotrnosti novih parkirnih hiš, hkrati pa se dnevno srečujemo z močno obremenjenimi parkirišči v središču mesta, zaparkiranimi pločniki in kolesarskimi stezami ter domala praznimi parkirišči na obrobju mesta.

V Münstru je na podobno širokem območju mestnega jedra in okolice potniške postaje, okoli 7.500 parkirnih mest (Jahres Statistik - Stadt Münster, 2006). Večina parkiriščih okoli postaje in na samem vstopu v staro mestno jedro je v parkirnih hišah, še več odprtih parkirišč pa nameravajo $\mathrm{v}$ prihodnje nameniti drugi rabi ter jih preseliti v podzemne garaže.

\section{JAVNI MESTNI POTNIŠKI PROMET}

Zanimivo je, da je bil prvi javni potniški promet, tako v Münstru kot v Ljubljani tramvaj. V obeh mestih je bil uveden leta 1901. Kasneje sta obe mesti tramvaj zamenjali za avtobusni potniški promet, ki pa se je v Ljubljani, predvsem v 70-ih in 80-ih letih, precej bolj razmahnil kot v Münstru. Najbrž tudi zato, ker je sama prostorska struktura Ljubljane veliko bolj primerna za rentabilno poslovanje linijskega potniškega prometa. V Münstru so se z ukrepi za povečanje uporabe javnega avtobusnega prometa začeli resneje ukvarjati konec 80 -ih let, $\mathrm{v}$ istem obdobju pa je promet Ljubljanskega potniškega prometa že začel stagnirati. Leta 2005 so bili kazalci avtobusnega javnega potniškega prometa obeh mest sledeči:

Preglednica 3: Primerjava kazalcev javnega mestnega prevoza v MOL in MS za leto 2005

Table 3: A comparative analysis of the public transport indicators in Ljubljana and Münster, 2005

\begin{tabular}{|l|c|c|}
\hline & LJUBLJANA & MÜNSTER \\
\hline Št. prepeljanih potnikov (v mio) & 89,8 & 31,5 \\
\hline Št. prevoženih kilometrov (v mio km) & 11,0 & 8,8 \\
\hline Št. avtobusov v uporabi & 201 & 122 \\
\hline Delež potovanj opravljenih z avtobusnim JPP & $13 \%$ & $10,5 \%$ \\
\hline Povprečna potovalna hitrost mestnih avtobusov & $10-15 \mathrm{~km} / \mathrm{h}$ & $26 \mathrm{~km} / \mathrm{h}$ \\
\hline
\end{tabular}

Vir: Zweckverband SPNV Münsterland, 2007; Služba za mestno statistiko in analize MOL, 2007; Verkehr in Zahlen 2005; Bole, 2003.

Zmogljivosti javnega potniškega prometa $\mathrm{v}$ obeh mestih se močno razlikujejo, saj se v Ljubljani število potnikov letno giblje okoli 90 milijonov, v Münstru pa nekaj čez 30 milijonov. V zadnjem desetletju je opaziti vztrajno padanje uporabe mestnega potniškega prometa v Ljubljani ter pozitiven trend v Münstru.

Pri vsem je potrebno dodati, da je v Münstru in njegovi širši regiji velik uspeh v javnih prevozih prineslo poenotenje informacijskega, tarifnega in logističnega sistema, ki zajema tako mestni avtobusni, regionalni avtobusni in železniški potniški promet ter mestni promet $\mathrm{v}$ drugih mestih regije. Poleg tega železniški sistem, s premišljeno razporejenimi železniškimi postajami, v veliki meri služi tudi dopolnitvi mestnega avtobusnega prometa. Celoten sistem javnega potniškega prometa regije je brezplačen za vse študente, dijake in šolarje. 
Slika 2 in 3: Gibanje števila avtobusov, prepeljanih potnikov (vmio) in prevoženih km avtobusnega javnega prometa (v mio) v Münstru in Ljubljani; časovni niz 1990-2005

Figure 2 and 3: Number of buses, passengers (mio) and distance (km) done by the bus public transport of Ljubljana and Münster; 1990-2005
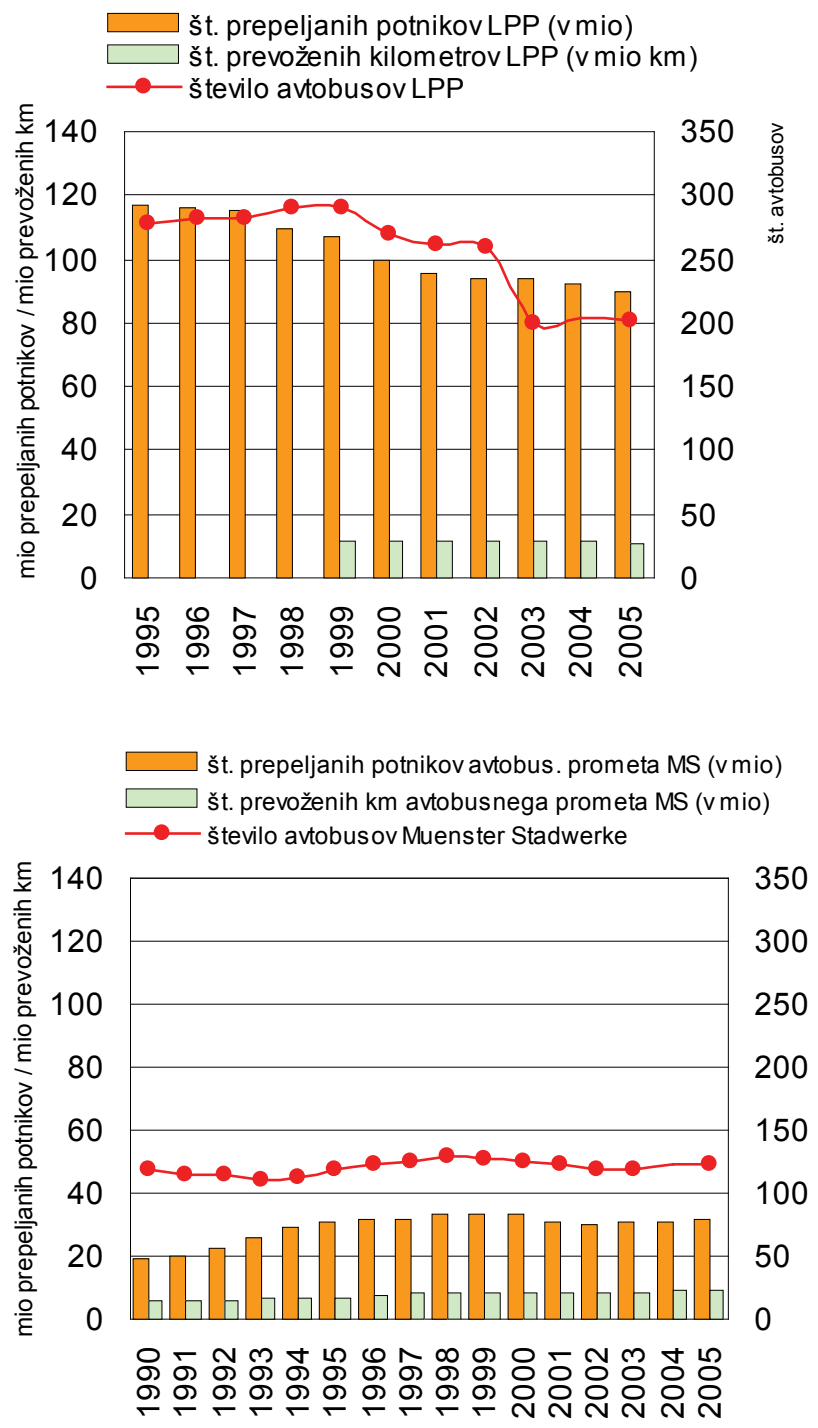

Vir: Zweckverband SPNV Münsterland, (citirano 2007); Služba za mestno statistiko in analize MOL, (citirano 2006). 
V Ljubljani se kaže kot eden večjih problemov ravno slaba organizacija in nepovezanost različnih prevoznikov, poleg tega pa je izredno slabo tudi sodelovanje občinske in državne ravni ter javnih podjetij potniškega prometa.

Kljub konkretnim ukrepom v Münstru za povečanje uporabe mestnega avtobusnega prometa in poskusom zajezitev padanja le-tega v Ljubljani, pa je očitno da:

- v Münstru mestni potniški avtobusni promet ne more konkurirati kolesu,

- $\quad$ L Ljubljani mestni potniški avtobusni promet ne more konkurirati avtomobilu.

\section{I0. KOLESARSKI PROMET}

Bolj kot pri kateremkoli drugem prometnem podsistemu, se že na bežen pogled razkriva velika razlika v kolesarskem prometu med Münstrom in Ljubljano. Münster velja za kolesarsko mesto tudi v svetovnem merilu, temu primerna pa je celotna kolesarska infrastruktura in urejanje prometa, ki v več pogledih daje prednost kolesarjem.

Preglednica 4: Primerjava kazalcev kolesarskega prometa v Ljubljani in Münstru za leto 2003 Table 4: A comparative analysis of the cycling indicators in Ljubljana and Münster, 2003

\begin{tabular}{|l|c|c|}
\hline & LJUBLJANA & MÜNSTER \\
\hline Dolžina kolesarskih stez $(\mathrm{km})$ & 78 & 275 \\
\hline Delež potovanj opravljenih s kolesom & $10,0 \%$ & $35,5 \%$ \\
\hline
\end{tabular}

Vir: Jahres Statistik - Stadt Münster, 2006; Verkehrsbild Münster, 2003; Anketa po gospodinjstvih, 2003.

Slika 4: Odprte parkirne površine za kolesa ob glavni potniški postaji v Münstru

Figure 4: Open parking space for bicycles at the main railway station in Münster

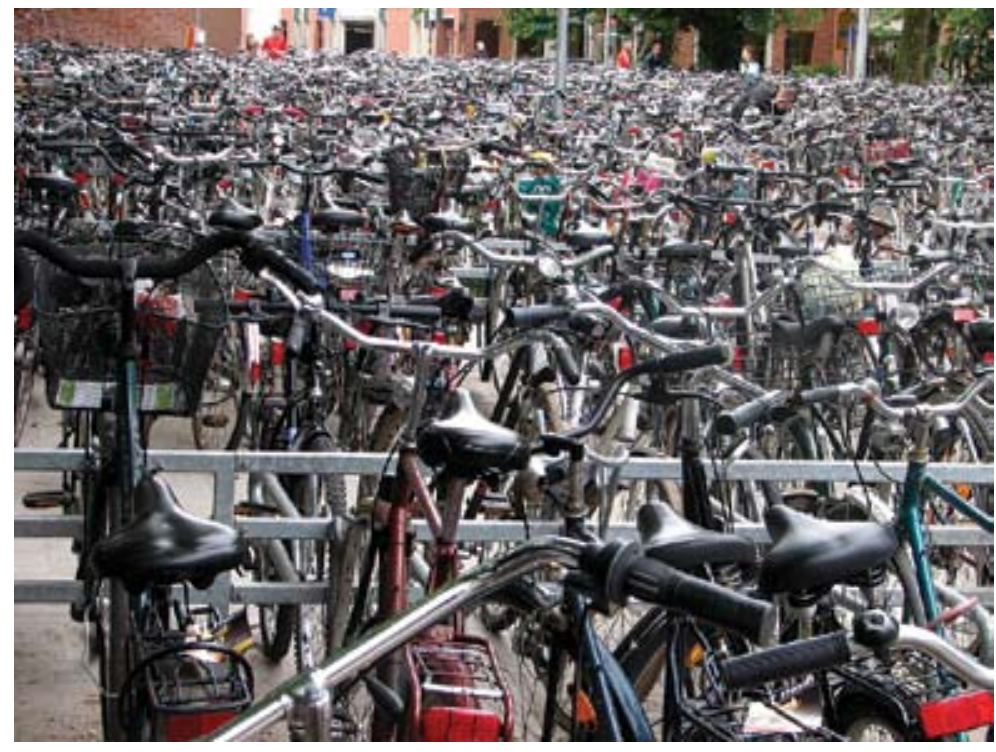


Medtem ko je v Ljubljani kolesarstvo najbolj zapostavljena oblika potovanja, omrežje stez pa ne dosega niti 80 kilometrov, je Münster na gosto prepleten s kolesarskim omrežjem, močno pa skrbijo tudi za izboljševanje varnosti, sistema smerokazov, možnosti prestopanja ter vzpostavitev čimbolj neposrednih povezav, ki še skrajšujejo čas potovanja.

Pri tem je potrebno poudariti, da množična uporaba kolesa ni le stvar dobre infrastrukture in ugodno urejenega prometa, pač pa tudi stvar kulture in mentalitete ljudi. Münster ni postal nemška prestolnica kolesarstva po naključju, pač pa na račun vztrajne in dolgoletne prometne politike, ki je sčasoma oblikovala mit kolesarstva.

Ljubljana na žalost trenutno nima niti infrastrukturne podlage za kolesarski promet, poleg tega pa je »potovalno« kolesarstvo premalo integrirano v navade in vrednote prebivalstva.

\section{POTNIŠKA VOZLIŠČA IN PROMETNE POVEZAVE Z REGIJO}

Münster in Ljubljana imata ustrezno gravitacijsko zaledje, ki je funkcijsko in prometno povezano z mestom. Obe mesti imata $\mathrm{v}$ osnovi cestni, železniški in kolesarski prometni sistem, ki zvezno prehaja v regijo.

Poleg glavne točke prestopanja - glavne potniške postaje, so za dobro funkcioniranje celotnega prometnega sistema pomembne tudi sekundarne točke, ki jih določajo cestna vozlišča, stičišča železniškega, cestnega ter kolesarskega sistema in stičišča različnih nosilcev javnega prometa. V Münstru obstajajo vse različice prestopnih točk - avto+JPP, avto+kolo, $\mathrm{JPP}+$ kolo - sistem prestopanja pa je zelo uspešen in $\mathrm{z}$ leti dobro sprejet s strani uporabnikov. Trenutno obstaja 11 takih točk, ki so namenjene prestopanju in menjavi potovalnega sredstva in so opremljena $\mathrm{z}$ vso potrebno infrastrukturo (informacijske table, urejeni parkirni prostori za kolesa, avtomati za vozovnice JPP itd). Razporejeni so na zunanjem obodu v mesto oziroma ob vpadnih cestah, distribucijskih obročih in trasah železnice.

V Ljubljani, za razliko od Münstra, sicer poznamo $\mathrm{P}+\mathrm{R}$ sistem, vendar je primer dejansko le vzorčen, saj deluje le še tisti na Dolgem mostu, kjer je tudi povezava linijskega prometa dokaj direktna in hitra. Dejstvo je, da ljudje ob vztrajni uporabi avta tudi niso pripravljeni uporabljati kombiniranih prevozov, saj jim »avto do središča« še vedno predstavlja najbolj ugoden prevoz.

$\mathrm{V}$ prihodnje vsekakor rabimo bolj učinkovit sistem $\mathrm{P}+\mathrm{R}$ ob vpadnicah, obvoznici in notranjih obročih, da se izognemo stalnim zastojem in pomanjkanju parkirnih mest v centru Ljubljane. Hkrati je potrebno pri tem tudi dokončno poskrbeti za zaključenost notranjih obročev, drugačno prometno ureditev $\mathrm{v}$ jedru mesta, hiter in udoben javni promet ter enoten tarifni sistem različnih nosilcev javnega potniškega prometa.

\section{POTOVALNE NAVADE PREBIVALCEV}

Izbira potovalnega načina (modal-split). Münster resnično (poleg avtomobila) izkazuje prevlado kolesarske kulture ter hkrati kaže pozitiven razvoj v smeri trajnostnega prometa. V nasprotju s tem Mestna občina Ljubljana izkazuje slabo strukturo izbire potovalnega sredstva, poleg tega pa se stanje še poslabšuje in vedno bolj kaže prevlado avtomobilskega prometa. Okolju prijazne opcije prevoza so v Ljubljani zapostavljene, resnici na ljubo 
je v okoliških občinah stanje še slabše. V splošnem se poleg avta ljudje največ poslužujejo pešačenja, kar kaže slabo organizacijo drugih vrst prevoza, ki zahtevajo nekaj več infrastrukture in vloženega dela (kolesarjenje, JPP).

Slika 5: Izbor prometnega sredstva v Ljubljani in Münstru

Figure 5: Modal split in Ljubljana and Münster

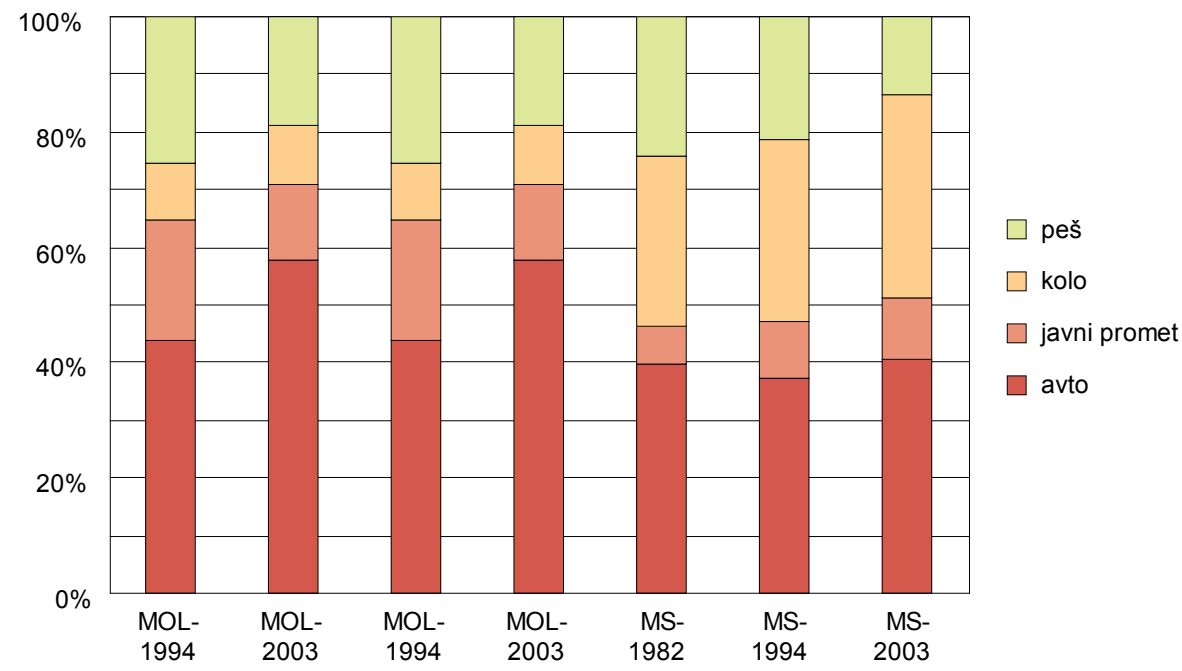

Vir: Verkehrsbild Münster 2003, 2003; Anketa po gospodinjstvih, 2003.

Lastništvo avtomobilov. Motorizacija prebivalstva oziroma število osebnih avtomobilov v obeh mestih narašča. Le-to je v Münstru po eni strani bolj upravičeno, saj hkrati, sicer po nižji stopnji, narašča tudi število prebivalstva. Nasprotno pa $v$ Ljubljani število avtomobilov raste $\mathrm{s}$ sočasnim padanjem števila prebivalstva.

Statistično gledano je enemu prebivalcu v Ljubljani leta 2003 pripadlo 0,42 avta, Münsterčanu pa kar 0,56 avta, kar kaže zanimivo dvojnost: prebivalstvo Münstra lasti v povprečju več avtomobilov kot prebivalstvo Ljubljane, vendar se Münsterčani z avtomobili vozijo bolj poredko. V tem smislu se jasno potrjuje teza, da populacija ljudi, ki živi v številnih in manjših gospodinjstvih, $\mathrm{v}$ povprečju in relativno gledano, lasti več avtomobilov oziroma je načeloma tudi $v$ drugih vidikih potrošnje bolj potratna.

V povezavi z manj številčnimi gospodinjstvi, je tudi zasedenost avtomobila v Münstru manjša in dosega v povprečju le 1,08 človeka na avto. To je tudi posledica dejstva, da se največ voženj $z$ avtom opravi zaradi dela, kjer pa je zasedenost že $v$ načelu navadno nižja. $V$ Ljubljani je povprečna zasedenost avta, razmeroma visoka (1,32 ljudi/avto), kar je odraz tega, da avto pri nas postaja skoraj nezamenljivo prometno sredstvo ob šibkih drugih opcijah. Dejstvo, da se je zasedenost $v$ zadnjem desetletju celo rahlo povišala, pa izkazuje tudi korelacijo $z$ višanjem deleža nedelovnih voženj. 
Slika 6: Število osebnih avtomobilov in število prebivalstva v Ljubljani in Münstru; 1996 - 2006 Figure 6: Number of inhabitants and personal vecihles in Ljubljana and Münster; 1996 - 2006

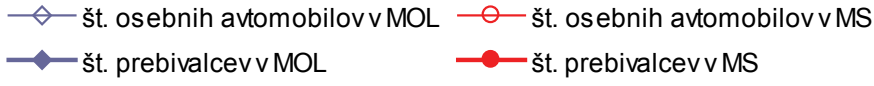

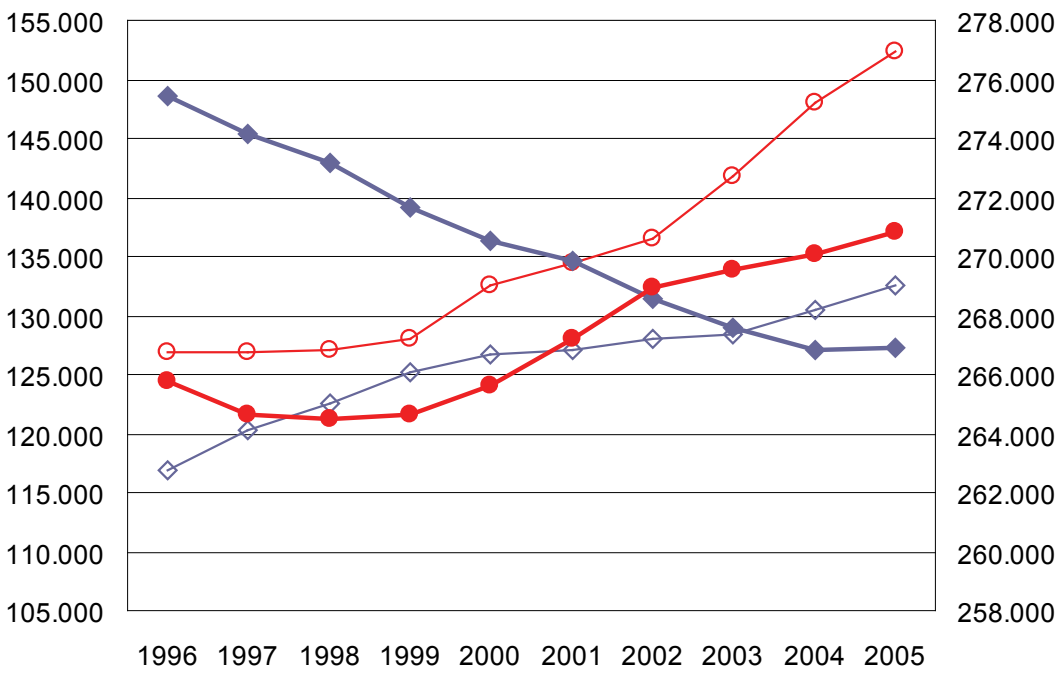

Vir: SURS; Služba za mestno statistiko in analize MOL, (citirano 2007);

Jahres Statistik-Stadt Münster, 2006; Stadtplanungsamt (citirano 2007).

Analiza namena potovanj v zadnjem desetletju kaže v obeh mestih porast nedelovnih voženj. Tovrstne težnje so rezultat današnjega načina življenja, ki je tudi (in predvsem) v okviru prostega časa zelo aktiven. Delež nedelovnih potovanj se bo v prihodnje še povečeval, saj je povezan z naraščajočo življenjsko ravnijo in z življenjskim slogom, ki se vse bolj uveljavlja in je značilen tudi za druga mesta v Evropi. To se zrcali tudi v dejstvu, da v splošnem narašča stopnja mobilnosti prebivalstva razvitega sveta, kar pomeni, da so danes ljudje veliko bolj prometno aktivni kot nekoč, manj časa prebijejo doma, več potujejo tudi starejši, skratka današnji način življenja je bolj dinamičen. V tem pogledu Ljubljana zaenkrat še zaostaja za Münstrom, saj je povprečno število potovanj/prebivalca opravljenih na delovni dan še vedno nižje (Ljubljana-3,11; Münster-3,81), vendar pa je stopnja rasti v zadnjem desetletji v Ljubljani višja.

Pri obeh mestih se kaže tudi podoben trend potovalnih navad okoliških prebivalcev, ki so v povprečju manj aktivni kot meščani, večji delež potovanj opravijo zaradi dela, hkrati pa so še bolj odvisni od avtomobila, kot meščani. 


\section{SKLEP}

Ljubljana in Münster v širšem prostoru izkazujeta sorazmerno enakovredno težo in funkcijsko razmerje do zaledja in sta razmeroma dobro primerljiva. Povezave in soodvisnost med prometnimi sistemi, mestnim okoljem, poselitvenim vzorcem, funkcijskimi žarišči, sodobnimi navadami in vrednotami ter številnimi drugimi faktorji prostora, so se izkazale za zelo kompleksne. Težko namreč pri preučevanju zajamemo celoten splet dejavnikov, ki vplivajo na prometne tokove, saj medsebojno součinkujejo, njihova interakcija pa se večkrat izkaže za prikrito in se kaže šele v daljšem obdobju.

V zadnjih petnajstih letih je politično, gospodarsko in socialno prestrukturiranje, ki ga je Slovenija doživljala po osamosvojitvi, pripeljalo tudi do precejšnjih sprememb v urbanem prostoru, predvsem v Ljubljani in njeni okolici. V tem obdobju je prišlo do zastoja pri snovanju in urejanju poselitvenih teženj, kar je dopuščalo stihijsko razraščanje gradnje in gostitve prebivalstva v zaledju Ljubljane. Takšnemu razvoju je spontano sledila reorganizacija tega prostora, tako v smislu funkcije krajev v zaledju, razporeditve delovnih mest, storitvenih, oskrbnih dejavnosti ter nenazadnje prometne ureditve območja. Ob premočnem razvoju individualnega motornega prometa, ki je sicer značilen tudi za druge države razvitega sveta, se je v veliki meri pokazala slaba prometna strukturiranost Ljubljane in okolice.

V Münstru se, tako z urejanjem prostora, kot s prometno politiko, intenzivno ukvarjajo že od obdobja prenove po 2. sv. vojni. V zadnjih dvajsetih letih rešujejo težave povezane s pojavom izseljevanja, suburbanizacije, hitro naraščajoče motorizacije, spremenjenega načina življenja in posledično večje mobilnosti prebivalstva. $Z$ omenjenimi problemi, ki so v močni soodvisnosti in sprožajo nove premike v prostoru, se v Münstru ukvarjajo zelo resno, čeravno se prostorske in prometne težave kažejo v veliko manjši meri kot v Ljubljani. V mestu se namreč zavedajo prostorskih posledic in problemov, ki jih prinašajo zgostitve prebivalstva v gravitacijskem zaledju Münstra, ter dnevno migracijski tokovi, povezani z zaposlitvijo in oskrbo ter izobraževanjem. Temu ustrezno se sooblikujejo dolgoročne in kratkoročne strategije na vseh ravneh načrtovanja. Posebej se izpostavljajo razvojni modeli: dekoncentrirano zgoščevanje, »mesto kratkih poti«, mešana raba tal, kompaktnost poselitve, hierarhija centrov, varčevanje z energijo itd. Poleg tega skušajo uravnavati neskladje v zaposlitvenih tokovih, stanovanjski politiki in načrtovanju komunikacij ter vzpodbujati uporabo javnega prometa pri vožnjah na delo in pri prostočasnih dejavnostih. Ena glavnih in stalno prisotnih prioritet prometne politike je že vrsto let kolesarstvo.

Ključna razlika v načrtovanju in posledično stanju prometa $v$ obeh analiziranih mestih:

- V Münstru se s problemi v prostoru ukvarjajo celostno in pravočasno. To pomeni, da ustrezno ukrepajo že v začetnih fazah negativnih teženj razvoja, ob tem pa sočasno prilagajajo smer ukrepanja in preučujejo možnosti rešitve in sicer v kontekstu vseh zaznanih in pričakovanih interakcij med različnimi faktorji prostora.

- V Ljubljani ob spreminjanju družbeno-geografskih razmer, ki se intenzivneje odvijajo že od začetka devetdesetih let, v želji po zmanjšanju najbolj očitnih in motečih problemov v prometu, zapostavljamo kratkoročno manj pereče probleme, kar povratno zmanjšuje njihove dolgoročne razvojne možnosti. Številne študije in razvojne strategije sicer ustrezajo celostni obravnavi razvoja Ljubljane in zaledja, vendar se v praksi ne izvajajo. 
Na podlagi ugotovljene povezanosti gospodarskega napredka s prebivalstvenim gibanjem in prometnimi tokovi, sem mnenja, da Ljubljana ne bi smela ponavljati preteklih vzorcev urejanja prometa, potrošnje prostora in energije ter odlašati z reševanjem okoljskih problemov. Koordinirano načrtovanje prometa in rabe prostora je $\mathrm{v}$ tem kontekstu nujno, saj potovanje in prostorska odločitev determinirata drug drugega.

V skladu z opravljeno primerjalno analizo prometa Ljubljane in Münstra, ugotavljam pomembne razlike $\mathrm{v}$ kakovosti strukture prometnega sistema teh dveh mest, hkrati pa izpostavljeno vlogo trajnostne mobilnosti v Münstru. Primerjava poraja številne pomisleke glede kakovosti prometa v Ljubljani, hkrati pa je Münster lahko vir idej za reševanje problemov prometa $\mathrm{v}$ naši prestolnici.

Predvsem bi poudarila naslednja dejstva in podala možne rešitve oziroma predloge:

- Rešitev problematike stoječega prometa, ozkih grl in zastojev ni v neprestanem širjenju prometne infrastrukture, saj spodbuja nove prometne tokove in posledično ustvarja ponovne prekoračitve zmogljivostnih kapacitet ter še bolj favorizira individualni motorizirani promet.

- Za uspešno spremljanje, nadziranje in načrtovanje cestnega prometa potrebujemo bolj natančne kazalce povprečne vrednosti intenzitete prometa od trenutno standardizirane enote PLDP. Bolj uporabne s strani novejših računalniških programov ter z gledišča primerljivosti v drugih evropskih mestih, so urne vrednosti konic.

- Kolesarjenje je idealna rešitev za prometne in okoljske probleme v mestih, sklada pa se Z vsako splošno politiko, ki želi izboljšati stanje prometa $v$ mestu, pri tem pa se opira na razmeroma skromna finančna sredstva. Kolo ne onesnažuje okolja, zavzame malo prostora, je tiho, gospodarno, finančno dostopno, zagotavlja neodvisnost od voznega reda, je zdravju koristno, predvsem pa je v mestu hitrejše in bolj fleksibilno od avtomobila. Ljubljana ima z naravno-geografskega gledišča celo bolj optimalne pogoje za kolesarjenje kot Münster.

- $\quad$ Največji problem javnega potniškega prometa v Ljubljani in Ljubljanski urbani regiji je nerazvitost $v$ smislu intermodalnosti in logistike.

- Potrebna je temeljita obnova javnega potniškga prometa, tako da bo hiter, udoben, učinkovit, kakovosten, cenovno konkurenčen, predvsem pa povezan in enostaven za uporabnike.

- Poenotenje vozovnic in potovalnih tarif ter skupni avtomati za vozovnice, so lahko uresničljivi v kratkoročnem obdobju. Sama ukinitev zastarelega sistema žetonov in plačevanja z gotovino nima smisla, če ne poskrbimo za sočasno uvajanje enotne vozovnice. Tu je nujno koordiniranje različnih nosilcev JPP, novosti in posodobitve v lastni režiji le-teh pa na dolgi rok niso smiselni.

- Da bi razbremenili cestni promet, je končno potrebno začeti uresničevati načrte posodobitve regionalne železnice ter morebitno uvajanje mestne železnice. Ker predstavlja uvedba mestne železnice velik finančni zalogaj in razmeroma dolgotrajen proces gradnje, lahko začnemo pri doslednem uvajanju dodatnega rumenega pasu za avtobusni promet, $\mathrm{s}$ čimer se ta pas rezervira za namen cestišča in je v prihodnosti lahko izhodišče za lociranje tirne infrastrukture. 
- Ob odločitvi za nadaljnji razvoj javnega mestnega prometa $v$ obliki avtobusov, bi lahko ob sočasnem urejanju rumenega pasu, začeli s postopnim uvajanjem semaforizacije, ki je specifično prilagojena avtobusnemu prometu. $S$ tem se $v$ križiščih poveča pretočnost in hitrost ter konkurenčnost avtobusnega prometa v primerjavi z avtomobilskimi tokovi.

- Ožje mestno jedro v območju Kongresnega trga, Trga republike in Slovenske ceste do Ajdovščine bi, ob sočasni ureditvi napajalno distribucijskega sistema cest in parkirnih zmogljivosti na obrobju, lahko zaprli za večino prometa ter sčasoma oblikovali nedeljen prostor, namenjen predvsem pešcem in kolesarjem, kasneje lahko tudi trasi mestne železnice. To bi pripomoglo k višji kakovosti zraka, manjši obremenjenosti s hrupom, večji vizualni in funkcijski povezanosti prostora itd.

- Za začetek se lahko omenjeno območje Slovenske ceste v centru zoži za en pas, kar bi umirilo intenziteto tokov in odstopilo del prostora drugi rabi, hkrati pa se na ta način začne postopoma navajati prebivalstvo na zmanjšane pogoje motorizirane pretočnosti v centru mesta.

- Parkirišča na Kongresnem trgu in Trgu republike bi prestavili v podzemne garaže oziroma premestili na bolj obrobne lokacije mestnega jedra. $S$ tem bi pridobili še več prostega prostora, ki bi ga lahko namenili drugi rabi oziroma uredili v parkovna območja.

\section{Viri in literatura}

Anketa po gospodinjstvih, 2003. Raziskava potovalnih navad prebivalcev ljubljanske regije. Ljubljana, Oddelek za urbanizem MOL, 132 str.

Apel, D., Böhme, C., 2000. Szenarien und Potentiale einer nachaltige flächensparenden und landschaftschonenden Siedlungsentwicklung. Berlin, Erich Schmidt, 480 str.

Bole, D., 2003. Javni potniški promet in raba zemljišč v Mestni občini Ljubljana : diplomsko delo. Ljubljana, Filozofska fakulteta, Oddelek za geografijo, 114 str.

Černe, A., 2002. Javni potniški promet kot izraz gravitacijske moči Ljubljane. V: Geografija Ljubljane. Ljubljana, Filozofska fakulteta, Oddelek za geografijo, str.191-213.

Direkcija Republike Slovenije za ceste. Prometne obremenitve 1992-2005. URL: http://www. dc.gov.si/si/promet/, (citirano april 2007).

Focus-društvo za sonaravni razvoj. URL: http://www.focus.si/index.php, (citirano 2006).

Guzelj, T., 1991. Mestna železnica v Ljubljanji. Ljubljana, Skupnost za ceste, 259 str.

Guzelj, T., 2001. Prostorska zasnova, področje promet, integralna zasnova prometnega sistema MOL : strok. podlaga. Elaborat 4, končna verzija. Ljubljana, Oddelek za urbanizem MOL, 25 str.

Kušar, S., 2003. Problemska regija kot element za zasnovo regionalnega razvojnega programa: magistrsko delo. Ljubljana, Filozofska fakulteta, Oddelek za geografijo, 147 str.

Ministrstvo za notranje zadeve. Podatki s področja prometa. 1999-2006. URL: http://www.

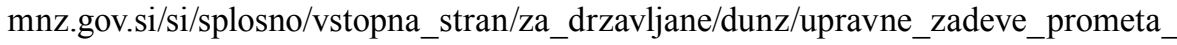
vozniki_in_vozila/statisticni_podatki_s_podrocja_prometa/, (citirano 5.3.2007).

Münster 2010, Planungen und Projekte fur ein zukungsfahiges Münster - Grundlagen fur 
die Fortschreibung des Flachennutzungsplanes 2010. 2000. Münster, Stadtplanungsamt, 72 str.

Parkirišča Ljubljana. URL: http://www.jh-lj.si/index.php?p=8, (citirano 22.3.2007).

Pichler-Milanović, N., 2001. Primerjalne ali konkurenčne prednosti Ljubljane v procesu evropskih integracij. Urbani izziv, 12, 1, str. 69-85.

Prostorska zasnova. Prostorski plan Mestne občine Ljubljana. 2002. Ljubljana, MOL, Oddelek za urbanizem, 132 str.

Resolucija o prometni politiki Republike Slovenije (Intermodalnost: čas za sinergijo). 2005. Ministrstvo za promet. URL: http//www.gov.si./mpz/2kabinet/2k-3.html\#16, (citirano 2007).

Richard-Wiegandt, U., 2005. Münster und seine Stadtteile. Münster, Aschendorff Verlag, 239 str.

Služba za mestno statistiko in analize MOL. Statistični letopis Ljubljane 2005. URL: http:// www.ljubljana-tourism.si/si/mol/mestna_uprava/cvi/publikacije/47505/podrobno.html,

Stadt Münster. Jahres-Statistik 2006. URL: http://www.muenster.de/stadt/stadtplanung stadtentwicklung-publikationen.html, (citirano april 2007).

Stadt Münster. Verhehrsplanung. Verkehr in Zahlen.URL:http://www.muenster.de/stadt stadtentwicklung/pdf/jahres-statistik-2005.pdf, ( citirano 3.4.2007).

StadtMünster. Verkehrsbild Münster 2003.URL:http://www.muenster.de/stadt/stadtplanung/ verkehrszahlen_bild.html, (citirano jan. 2007).

Stadwerke Münster. Informationen zum Nahverkehr. URL: http:/www.stadtwerke-muenster. de/fahrgaeste/service/mobile/mobile.php, (citirano januar 2007).

Statistični urad Republike Slovenije. SI-STAT podatkovni portal: URL: http://www.stat.si/ pxweb/Dialog/statfile2.asp, (citirano 4.12. 2006).

Šašek Divjak, M., 2004. Prometni koridorji in poselitev v regiji: navezovanje poselitve na javni promet. Urbani izziv, 16, 1, str. $19-27$.

Trajnostna mobilnost. Focus, društvo za sonaravni razvoj. URL: http://www.focus.si/index. php? node=129, (citirano 3.3. 2007).

Upravljanje in brzdanje mestnega prometa. Rezultati raziskovalnih projektov, financiranih s strani EU o prometu v mestih, 2003, 219 str. URL: http://www.eu-portal.net, (citirano 2.5.2006).

Zveckverband. Schienenpersonennahverkehr. URL: http://www.zvm.info./, (cit. maj 2007).

\section{TRAFFIC OF LJUBLJANA AND MÜNSTER URBAN AREAS}

\section{Summary}

The comparison of traffic conditions in Ljubljana and Münster was made by studying the indicators of all basic components of space which have an important influence on traffic flows in a city and a wider city region. The connections and co-dependence between traffic systems, city environment, settlement pattern, functional focal points, contemporary habits and values and numerous other factors of space have proved as very complex. Namely, when 
carrying out a study it is difficult to include the whole range of factors influencing traffic flows. The reason for this is that they mutually influence each other and their interaction many times proves as hidden and manifests itself only in a longer period of time.

In the first part of my research the validity of the assumption about a similar structure of spatial, social and economic characteristics of both cities, as well as the assumption about a similar intensity of processes triggering the same developmental tendencies, were confirmed. In wider space, Ljubljana and Münster demonstrate a proportionally equivalent weight and functional relation to the hinterland. Due to strong employment, educational, su-pply and service functions and a strong gravitational hinterland both cities represent an area of dynamic flow of people, and demand an effective, adaptable, well structured and economical traffic system.

In the last fifteen years the political, economic and social restructuring, which Slovenia has experienced since its attainment of independence, has led to considerable changes in urban space, above all in Ljubljana and its surroundings. In this period a deadlock at the planning and arrangement of settlement tendencies occurred, and this allowed an uncontrolled growth of construction and the crowdedness of population in the hinterland of Ljubljana. Such development was spontaneously followed by a reorganization of this space, not only from the point of view of the functions of the settlements in the hinterland, the arrangement of places of work, service and supply activities but also from the point of view of traffic regulation of the area. What came to light besides an excessive development of individual motor traffic, which is typical also of other developed countries, was a mainly bad traffic structure of Ljubljana and the surroundings.

The arrangement of space, as well as traffic policy in Münster have been intensively dealt with already from the period of renovation after the World War II. In the last twenty years they have been solving the problems connected with the appearance of emigration, suburbanisation, quickly growing motorization, changed way of living and consequently bigger mobility of population. The mentioned problems, which are in a strong co-dependence and trigger new movements in space, are dealt with very seriously in Münster, even though the space and traffic problems are present in a much smaller extent than in Ljubljana. Namely, in the city they are aware of the space consequences and problems brought by the crowdedness of population in the gravitational hinterland of Münster and daily migrational flows connected with employment, supply and education. For many years, cycling has been one of the main and permanently present priorities.

Here I can point out the key difference in the planning and consequently the state of traffic in both analysed cities:

- In Münster, the changing problems in space are dealt with wholistically and in time. This means that they react in an appropriate way already in the begging phases of negative tendencies of development and at the same time they adapt the direction of measures and study the possibilities of solving the problems within the context of all perceived and expected interactions between different factors of space.

- In Ljubljana, along with the changes of socio-geographic conditions, which have been happening more intensively since the beginning of the nineties, problems which are in a short term less urgent are neglected, the reason for this being the wish for decreasing the 
most obvious and disturbing problems in traffic. However, in return this decreases their long term developmental possibilities. Numerous studies and developmental strategies suit a wholistic treatment of the development of Ljubljana and, but in practice, they are not carried out.

The ascertained connection of geographic progress with population movement and traffic flows makes me believe that Ljubljana should not repeat the past patterns of traffic regulation, consumption of space and energy and postpone the solving of environmental problems. Since travelling and location decision determine each other, coordinated planning of traffic and the use of space are a necessity. 